Конарівська О. Б., к.е.н., доцент, Кушнір Н. Б., к.е.н., професор, Яковишина М. С., ст. викладач (Національний університет водного господарства та природокористування, м. Рівне)

\title{
ХАРАКТЕРИСТИКА МЕХАНІЗМУ ДЕРЖАВНОГО УПРАВЛІННЯ ТУРИСТИЧНОЮ ГАЛУЗЗЮ
}

В статті визначено зміст механізму державного управління туристичною галуззю, проведена характеристика його складових елементів: об'єкт, суб'єкт, інструменти, методи та форми управління, організаційне, інформаційне, кадрове, науково-методичне та матеріально-технічне забезпечення.

Ключові слова: туристична галузь, механізм державного управління, інструменти, методи і форми управління, організаційне, інформаційне, кадрове, науково-методичне та матеріально-технічне забезпечення.

В сучасних умовах вітчизняна туристична галузь відіграє для національної економіки стратегічне значення: сприяє становленню країни на світовому ринку товарів і послуг і зростанню податкових надходжень до бюджетів усіх рівнів, підвищує рівень не тільки конкурентоспроможності економіки країни, а й рівень соціального, культурного, природного та людського потенціалів. Проте, сфера туризму в Україні знаходиться на недостатньому рівні у порівнянні з розвинутими країнами світу. Про це свідчать ряд системних проблем, зокрема недосконала нормативно-правова база, що впливає на податкову політику та інвестиційний клімат для інтенсивного розвитку в"їзного та внутрішнього туризму, нерозвинена туристична інфраструктура, яка стримує розвиток туризму в регіонах країни, низька платоспроможність населення, що впливає на його туристичну активність тощо. Побороти ці проблеми можливо шляхом створення ефективного механізму державного управління туристичною галуззю, що забезпечуватиме подальший розвиток туризму як рентабельної галузі національної економіки.

Дослідженням механізму державного управління туристичною галуззю займались такі вітчизняні науковці, як М. Біль [2], М. Борущак [3], Л. Давиденко [4], Є. Козловський [5], О. Крайник [2], Г. Третяк [2] та багато інших.

Незважаючи на велику кількість наукових публікацій із зазначеної проблематики, не існує єдиного підходу до створення і функці- 
онування механізму державного управління туристичною галуззю, тому питання характеристики механізму державного управління туристичною галуззю потребує більш глибшого вивчення.

Метою даної статті $€$ визначення підходів щодо функціонування механізму державного управління туристичною галуззю та характеристика його складових елементів.

Існує багато визначень механізму державного управління у сфері туризму. Аналіз наукових праць [2-5] дозволив виділити такі підходи:

- сукупність засобів організації управлінських процесів і способів впливу на розвиток керованих об'єктів, що базуються на принципах наукової обґрунтованості, об'єктивності, цілісності, узгодженості з використанням відповідних методів управління, спрямованих на реалізацію цілей державного управління [2, С.18];

- напрям державної туристичної політики разом з розробкою концепцій розвитку туризму в регіонах, що формує цільові програми стосовно розвитку туризму на рівні адміністративного центру в цілому і на рівні окремого суб'єкта адміністрування [3, С. 12];

- повноваження держави щодо формування і підтримки туристично-рекреаційного середовища, регулювання обсягів і напрямів туристичних потоків, створення туристичної інфраструктури, охорони рекреаційних ресурсів і заповідних територій, організації відпочинку та вільного часу населення країни, підготовки кадрів для рекреаційних туристичних комплексів [4, С. 7];

- сукупність організаційно-економічних методів та інструментів, за допомогою яких виконуються взаємопов'язані функції для забезпечення сталого розвитку туризму [5, С. 7-8].

3 вищесказаного видно, що у науковців не має єдиного підходу до визначення поняття «механізм державного управління туристичною галуззю», а представлені - не відображають склад і специфіку галузі як об'єкта управління.

У Законі України «Про туризм» зазначено, що метою державного управління туристичною галуззю $€$ [1]: забезпечення прав громадян на відпочинок, свободу пересування, зміцнення здоров'я, задоволення духовних потреб; забезпечення безпеки туризму, збереження цілісності туристично-рекреаційних ресурсів, охорони культурної спадщини; створення сприятливих умов туристичної діяльності; збереження історико-культурної спадщини, охорона навколишнього середовища.

Розуміння механізму державного управління практично у більшості визначень зводиться до виділення таких його первинних ознак, як штучно створений організм; практичний характер функціона- 
льного призначення; системність, комплексність та взаємоузгодженість елементів, що його формують.

Виходячи з даного трактування поняття, структура і основні елементи механізму матимуть такий вигляд (рис. 1).

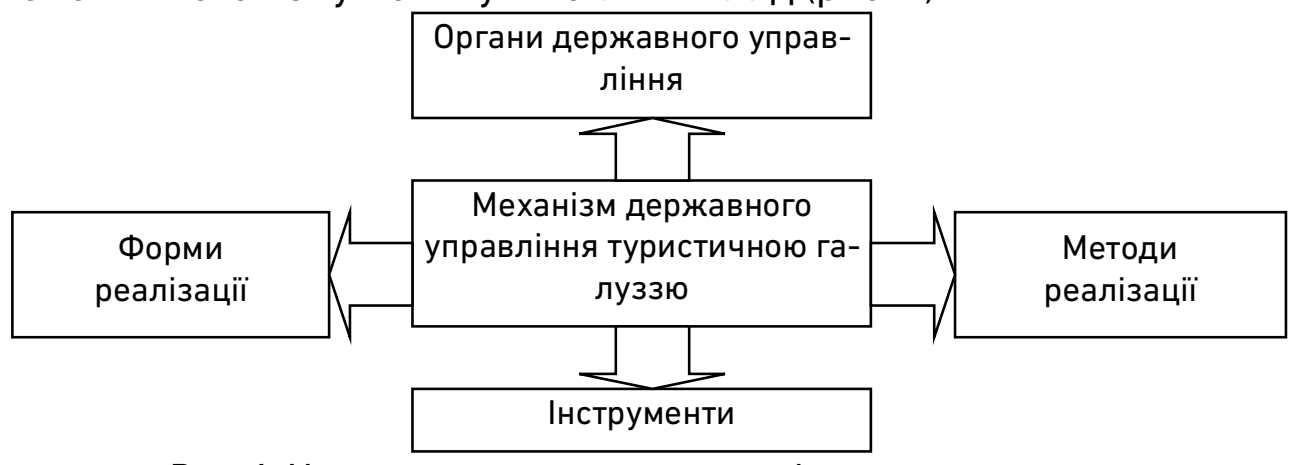

Рис. 1. Узагальнена структура механізму державного управління туристичною галуззю

Джерело: розробка авторів

Отже, для розуміння суті механізму державного управління туристичною галуззю насамперед необхідно визначити базові поняття, що їі характеризують, зокрема інструменти методи і форми їх реалізації.

На підставі досвіду вітчизняних науковців, можна сформувати головні принципи, які використовуються при розробці механізму державного управління туристичною галуззю [2-5]:

- системність - розподіл складових механізму державного управління за конкретними системами (підсистемами), які мають власну структуру;

- комплексність - ефективність механізму можлива лише за умов комплексної дієвості всіх складових (підсистем);

- компліментарність (принцип компенсації) - без дієвість одних підсистем гальмує дієвість інших підсистем, що в кінцевому результаті створює дефекти механізму; недоліки одних підсистем можуть бути компенсовані перевагами інших підсистем;

- функціональність - кожна підсистема має чітке функціональне призначення та повинна бути організована таким чином, щоб у сприятливих умовах реалізовувати свої можливості щодо виконання покладених на неї функцій;

- регламентованість - кожна підсистема реалізує своє функціональне призначення в межах чинного законодавства;

- галузева дотичність - урахування діяльності суміжних з туризмом галузей, які або суттєво впливають на галузь, або залежні від неї.

До методів, що забезпечують реалізацію механізму державного 
управління туристичною галуззю відносяться:

- адміністративні - сукупність прийомів і впливів, що ґрунтуються на використанні організаційних принципів управління (прямий вплив на суб'єктів ринку туристичних послуг шляхом встановлення його повноважень (прав і обов'язків);

- економічні - сукупність способів впливу шляхом створення економічних умов, що спонукають учасників ринку туристичних послуг діяти в потрібному напрямі та виконувати поставлені завдання щодо розвитку (вимоги до регулювання цін, регулювання прибутків тощо);

- психологічні методи допомагають врегульовувати відносини між людьми (методи професійного підбору та навчання, психологічного стимулювання (мотивації), комплектування малих груп і колективів, гуманізації праці;

- інші - це такі методи впливу як примус і переконання. Примус складається з дисциплінарних, адміністративних, матеріальних, кримінально-процесуальних заходів, застосовується уповноваженими органами в межах їх правової компетенції та може здійснюватися через заходи адміністративного попередження і припинення, заходи адміністративно-процесуального забезпечення і адміністративного стягнення. Переконання передбачає виконання таких заходів: агітації, виховання, роз'яснення, показ позитивного досвіду, заохочення, які проводяться державними та громадськими органами, з метою формування у громадян та учасників ринку чіткого розуміння необхідності виконання різного роду вимог.

До переліку інструментів нами віднесено наступні: система планів та бюджетування, тактичні плани розвитку сегментів ринку; оперативні плани поточної діяльності професійних учасників ринку; програми та проекти; збалансована система показників тощо.

Суб'єктами державного управління в туристичній галузі виступає держава в особі їі органів (Верховна Рада України, Кабінет Міністрів України, органи місцевого управління та саморегулювання).

Об'єктами ж є: туристична галузь загалом; туристичнорекреаційний регіон; окремий вид туризму; потреби туристів (реальних та потенційних).

До механізму державного управління туристичною галуззю, окрім суб'єктів та об'єктів, методів, інструментів і форм їх реалізації, належить також організаційне, інформаційне, кадрове, науковометодичне та матеріально-технічне забезпечення. Розглянемо їх детальніше.

Під організаційним забезпеченням державного управління туристичною галуззю розуміємо систему державних та недержавних 
організаційних структур, які утворені на різних управлінських рівнях та реалізують свої рішення за допомогою методів та форм, що належать до їх повноважень.

Інформаційне забезпечення - комплекс різних видів етнокультурної, соціальної, природно-географічної, економічної інформації, що характеризує галузь, інструменти збирання відповідних первинних даних, їх систематизації, обробки, збереження, пошуку і поширення.

Кадрове забезпечення - підготовка та підвищення кваліфікації державних службовців, які здійснюють професійну діяльність в органах державної влади різного управлінського рівня.

Науково-методичне забезпечення - науково-методичні та теоретико-методологічні напрацювання щодо державного управління туристичною галуззю конкретно, які можуть бути основою прийняття управлінських рішень і базуються на основі ціннісного, структурносистемного, раціонального, критичного, конструктивного, порівняльноретроспективного, логічного підходів та їх поєднань.

Матеріально-технічне забезпечення включає накопичення, зберігання та розподіл фінансових і матеріальних ресурсів, спрямованих на забезпечення виконання прийнятих управлінських рішень чи утримання відповідних організаційних структур, до повноважень яких належить реалізація державної політики на відповідному рівні.

Компонуючи форми, методи, інструменти і враховуючи особливості ринку туристичних послуг, зобразимо механізм державного управління туристичною галуззю (рис. 2).

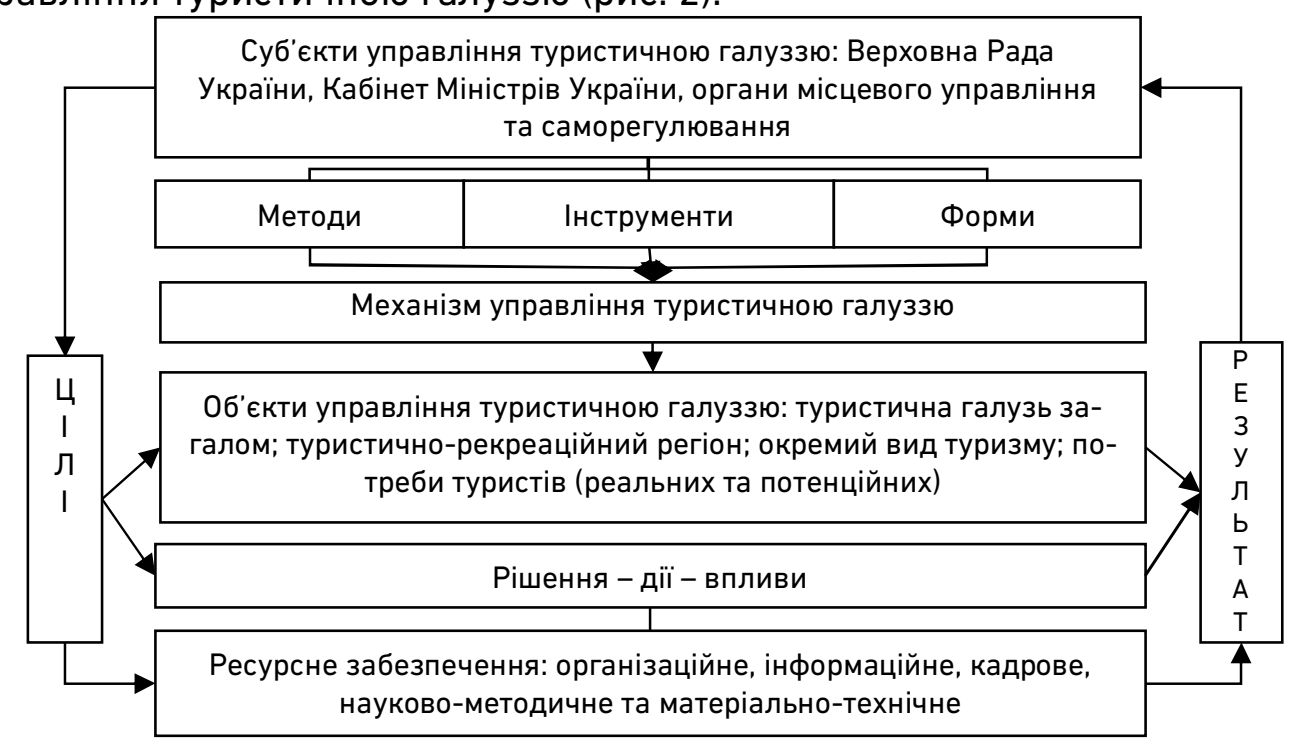

Рис. 2. Механізм державного управління туристичною галуззю України Джерело: розробка авторів 
Варто відмітити, що розуміння і визначеність механізму державного управління туристичною галуззю забезпечує реалізацію інтересів і суб'єктів державного управління, і об'єктів, і громадян України.

Отже, механізм державного управління туристичною галуззю - це сукупність інструментів, форм і методів цілеспрямованого впливу органів державної влади на розвиток об'єктів туристичної галузі, і створення умов для ефективної співпраці органів державної влади, місцевого самоврядування та приватного сектора щодо розвитку туризму, які дозволять сформувати системні засади розвитку галузі, завдяки яким, відповідно до поставлених цілей, наявного ресурсного забезпечення, обраних управлінських вимог, істотно підвищується рівень ефективності управління туризмом в Україні.

1. Про туризм : Закон України від 15.09.1995 р. № 324/95. URL: http://zakon.rada.gov.ua/laws/show/324/95-\%D0\%B2\%D1\%80. (дата звернення: 15.11.2018). 2. Біль М., Третяк Г., Крайник О. Механізм державного управління туристичною галуззю (регіональний аспект) : наук. розробка Київ, 2009. 40 с. 3. Борущак М. Проблеми формування стратегії розвитку туристичних регіонів : монографія. Львів, 2006. С. 12. 4. Давиденко Л. І. Державне регулювання сфери туризму на обласному рівні : автореф. дис. ... канд. наук з держ. упр. : 25.00.02. Донецьк, 2006. 23 с. 5. Козловський $€$. В. Державне регулювання в галузі туризму : становлення та розвиток в Україні : автореф. дис. ... канд. наук з держ. упр. : 25.00.02. Київ, 2008. С. 7-8.

\section{REFERENCES:}

1. Pro turyzm : Zakon Ukrainy vid 15.09 .1995 r. № 324/95. URL: http://zakon.rada.gov.ua/laws/show/324/95-\%D0\%B2\%D1\%80 (data zvernennia: 15.11.2018). 2. Bil M., Tretiak H., Krainyk O. Mekhanizm derzhavnoho upravlinnia turystychnoiu haluzziu (rehionalnyi aspekt) : nauk. rozrobka Kyiv, 2009. 40 s. 3. Borushchak M. Problemy formuvannia stratehii rozvytku turystychnykh rehioniv : monohrafiia. Lviv, 2006. S. 12. 4. Davydenko L. I. Derzhavne rehuliuvannia sfery turyzmu na oblasnomu rivni : avtoref. dys. ... kand. nauk $z$ derzh. upr. : 25.00.02. Donetsk, 2006. 23 s. 5. Kozlovskyi Ye. V. Derzhavne rehuliuvannia v haluzi turyzmu : stanovlennia ta rozvytok v Ukraini : avtoref. dys. ... kand. nauk z derzh. upr. : 25.00.02. Kyiv, 2008. S. 7-8.

Рецензент: д.е.н., професор Савіна Н. Б. (НУВГП) 
Konarivska O. B., Candidate of Economics (Ph.D.), Associate Professor Kushnir N. B., Candidate of Economics (Ph.D.), Professor, Yakovyshyna M. S., Senior Lecturer (National University of Water and Environmental Engineering, Rivne)

\section{CHARACTERISTICS OF STATE MANAGEMENT MECHANISM IN TOURISM INDUSTRY}

The article, on the basis of scientific approaches and current Ukrainian legislation, defines the content of the mechanism of state administration of the tourism industry. The characteristic of the constituent elements of the management mechanism in the field of such as: objects, subjects, tools, methods and forms of management, organizational, informational, personnel, scientific, methodological and material and technical support has been carried out.

The authors proposed a generalized structure of the mechanism of state management of the tourism industry, which served as the basis for the construction of a modern mechanism of public administration of the tourism industry of Ukraine. Such a mechanism is a set of tools, forms and methods of purposeful influence of public authorities on the development of objects of the tourism industry. It creates the conditions for effective cooperation of state authorities, local government and the private sector in the development of tourism and allows you to create systemic bases of development in accordance with the objectives, available resources, and management requirements. The use of the mechanism implies a significant increase in the level of efficiency of tourism management in Ukraine. Keywords: tourism industry, the mechanism of public administration, tools, methods and forms of management, organizational, informational, personnel, scientific, methodological and material and technical support.

Конаривская О. Б., к.э.н., доцент, Кушнир Н. Б., К.э.н., профессор, Яковишина М. С., ст. преподаватель (Национальный университет водного хозяйства и природопользования, г. Ровно)

ХАРАКТЕРИСТИКА МЕХАНИЗМА ГОСУДАРСТВЕННОГО УПРАВЛЕНИЯ ТУРИСТИЧЕСКОЙ ОТРАСЛЬЮ

В статье, на основе научных подходов и действующего украинского 
законодательства, определено содержание механизма государственного управления туристической отраслью. Проведено характеристику составляющих элементов механизма управления в области таких, как: объекты, субъекты, инструменты, методы и формы управления, организационное, информационное, кадровое, научно-методическое и материально-техническое обеспечение.

Авторами предложено обобщенную структуру механизма государственного управления туристической отраслью, которая послужила основой для построения современного механизма государственного управления туристической отраслью Украины. Такой механизм представляет собой совокупность инструментов, форм и методов целенаправленного воздействия органов государственной власти на развитие объектов туристической отрасли. Он создает условия для эффективного сотрудничества органов государственной власти, местного самоуправления и частного сектора по развитию туризма и позволяет сформировать системные основы развития отрясли в соответствии с поставленными целями, имеющимся ресурсным обеспечением, управленческих требований. Использование механизм предполагает существенное повышение уровня эффективности управления туризмом в Украине.

Ключевые слова: туристическая отрасль, механизм государственного управления, инструменты, методы и формы управления, организационное, информационное, кадровое, научно-методическое и материально-техническое обеспечение. 